\title{
DOSSIÊ CAPITAL SOCIAL E COMPORTAMENTO ELEITORAL
}

Uma das questões centrais do processo de construção da democracia na América Latina diz respeito ao grau de sofisticação política alcançado pelos cidadãos em relação ao Estado. Nesta dimensão, um conceito que tem assumido saliência, nos últimos anos, é o de capital social. Até que ponto as redes, laços sociais e confiança recíproca, por meio dos quais as pessoas se conectam têm fortalecido a chamada sociedade civil e melhorado, ou não, a relação entre Estado e sociedade?

A preocupação em avaliar se o tecido social incide ou não no fortalecimento da democracia ainda está num estágio intermediário de pesquisa, pois, existem estudos que mostram discrepâncias significativas entre si. Essa situação se complica ainda mais quando se compara o progresso da democracia formal, por um lado, e avanços da democracia social, por outro. Constata-se uma assimetria entre avanços importantes de caráter institucional ao mesmo tempo em que problemas de natureza material (saúde, moradia, segurança e educação) estão longe de serem resolvidos. Qual a consequência desse paradoxo, no desenvolvimento e construção da democracia e na institucionalização de uma cultura política crítica e participativa?

Pensamos que problematizar essa questão é oportuno e relevante, em face de lacuna evidente desse debate na agenda política dos nossos países. 0 desafio reside, nos parece, em abordar a questão da democracia, sem insinuar que aspectos institucionais não sejam importantes, da perspectiva do cidadão ou das relações sociais com base no capital social.

Cada vez mais estão disponíveis múltiplas fontes de dados, coletadas por diferentes redes de pesquisadores, que começam a permitir análises comparativas tanto no espaço como no tempo e com diferentes unidades políticas, das cidades aos países inteiros, devendo ser valorizado o trabalho dos autores que buscam fazer uso desta riqueza de informações não apenas no avanço de nossa disciplina, mas também na busca do enfrentamento dos problemas políticos e sociais.

Esta proposta fundamenta o dossiê Capital Social e Comportamento Eleitoral, apresentado neste número da Revista Debates. Os autores dos artigos se inspiraram em diferentes perspectivas teóricas e as abordagens metodológicas tentam responder a essas indagações.

O primeiro texto, de autoria de Laura Heras Gómez examina, com base em dados de diferentes pesquisas, como evoluiu nos últimos anos os níveis de confiança interpessoal e no Instituto Federal Eleitoral entre a população mexicana.

O segundo texto de Sonia Santos, Everton Santos, Cristina Ennes e Valdir Pedde, busca compreender o impacto do capital social sobre as políticas públicas com base em uma análise comparativa entre Porto Alegre e Montevidéu. 
A proposta do texto de João Ignácio Pires Lucas busca identificar o impacto dos Centros de Referência em Assistência Social na criação de capital social, tendo como fonte um survey realizado na cidade de Caxias do Sul, no Rio Grande do Sul.

Já o artigo de Ednaldo Ribeiro e Julian Borba examina se é possível, a partir de inovações institucionais participativas, produzir alterações no padrão de orientações subjetivas e atitudes dos cidadãos, tendo como foco a experiência do Orçamento Participativo em Porto Alegre.

Fechando o dossiê, o artigo de Marcello Baquero e Bianca Linhares analisa, do ponto de vista da cultura política, as causas da desconfiança dos brasileiros nos partidos e o que pode ser feito para melhorar esta situação.

Este número é complementado por três outros artigos. Adriano Oliveira analisa o fenômeno do "Lulismo" e como ele se apresenta no eleitorado brasileiro. Também nessa linha do entendimento, Teresinha Pires discute a construção da imagem de Dilma Rousseff como "mãe do Povo" na campanha eleitoral. O número fecha com uma discussão de Carlos Arturi sobre o estabelecimento de uma agenda de pesquisa sobre a consolidação da democracia no Brasil.

Acreditamos que um ponto de convergência comum a todos os artigos é o reconhecimento da necessidade de investir na revitalização da comunidade política, por meio de esforços que promovam o desenvolvimento de redes de cooperação com base na confiança recíproca, ou seja, capital social.

Marcello Baquero

Rodrigo Stumpf González 